\title{
Tahapan Pemilu 2019 di Tengah Ancaman Bencana Alam: Studi Kasus Erupsi Gunung Agung
}

\author{
Kadek Dwita Apriani ${ }^{1}$, Ni Made Ras Amanda Gelgel ${ }^{2}$ \\ ${ }^{1}$ Program Doktor IImu Politik FISIP Universitas Indonesia \\ ${ }^{2}$ Program Studi IImu Komunikasi FISIP Universitas Udayana \\ email: kadek88@gmail.com ${ }^{1}$, rasamanda13@unud.ac.id ${ }^{2}$
}

\begin{abstract}
ABSTRAK
Bencana erupsi gunung Agung di kabupaten Karangasem Bali merupakan salah satu di antara banyak bencana alam yang terjadi saat tahapan pemilu 2019 dilaksanakan. Penyelenggara pemilu setempat pasti mengalami hambatan dalam melaksanakan tahapan dalam kondisi demikian. Metode yang digunakan adalah metode penelitian kualitatif dengan wawancara mendalam sebagai teknik pengumpulan datanya. Temuan penelitian ini memperlihatkan bahwa (1) terdapat banyak aspek dalam tahapan pemilu yang terkena dampak di wilayah terpapar bencana, diantaranya daftar pemilih, logistik pemilu, verifikasi peserta pemilu, anggaran, sosialisasi, kampanye, pemungutan suara, dan tingkat partisipasi pemilih. (2) penyelenggara pemilu di kabupaten Karangasem Bali dapat mengatasi kondisi tersebut karena melakukan komunikasi dan koordinasi yang baik dengan stakeholder formal (BPBD dan Disdukcapil) dan stakeholder informal (Pasebaya Agung). Meski memang ke depannya sangat dibutuhkan aturan yang lebih jelas terkait penyelenggaraan pemilu di wilayah terdampak bencana.
\end{abstract}

Kata kunci: Pemilu, Bencana Alam, Gunung Agung.

\section{ABSTRACT}

The eruption of Mount Agung in Karangasem regency, Bali, was one of the many natural disasters that occurred during the 2019 election stage. The local election organizer must face obstacles in carrying out the stages in such conditions. The method used is a qualitative research method with in-depth interviews as a data collection technique. The findings of this study show that (1) there are many aspects of the election stage that are affected in disaster-affected areas, including voter lists, election logistics, election participant verification, budgeting, socialization, campaigns, voting, and voter participation rates. (2) election organizers in Karangasem regency can overcome these conditions due to good communication and coordination with formal stakeholders (BPBD and Disdukcapil) and informal stakeholders (Pasebaya Agung). Although in the future, clearer rules are needed regarding the holding of elections in disaster affected areas.

Keywords: election, natural disasters, Mount Agung.

\section{PENDAHULUAN}

Pemungutan suara Pemilu 2019 dilaksanakan pada 17 April 2019 namun tahapan pemilu diselenggarakan jauh sebelumnya. Tahapan yang panjang dihadapkan dengan beragam hambatan dan halangan. Hambatan yang tidak dapat dikendalikan 
oleh manusia yakni hambatan bencana alam. Sejak tahun 2018, Indonesia sebagai Negara yang berada di cincin api dunia, kerap terlanda bencana alam. Bencana alam yang terjadi pada masa tahapan pemilu antara lain ancaman bencana erupsi Gunung Agung di Kabupaten Karangasem, Provinsi Bali. Erupsi Gunung tertinggi di Bali ini terjadi sejak akhir 2017 hingga hari pemilihan umum berlangsung.

Bencana erupsi gunung agung merupakan salah satu persoalan penting dalam tahapan pemilu 2019 di provinsi Bali, khususnya di kabupaten Karangasem. Bencana alam pada tahapan pemilu paling sering dikorelasikan dengan ancaman hilangnya hak politik akibat bencana. Karenanya banyak pengamat yang mengingatkan KPU agar tidak ada hak politik yang hilang sebab itu berkaitan langsung dengan kualitas demokrasi kita. Beetham (2002) mengatakan kunci dari demokrasi adalah political equality. Konsep ini menekankan peran dan hak rakyat dalam politik dan bagaimana rakyat memperoleh perlakuan yang adil dan setara dalam menjalankan fungsi-fungsi demokrasinya.

Ardiapandanto (2019) dalam "Pemutakhiran Data Pemilih Tetap Pemilu 2019 di Daerah Bencana Alam" menegaskan untuk daerah yang terkena atau rawan bencana KPU tetap wajib memastikan tidak ada warga Negara yang kehilangan hak-hak politiknya. Hal yang harus dilakukan KPU adalah cross chek ulang DPTHP perbaikan ke-2, pencocokan dan penelitian (coklit), membentuk Pantarlih, menyelesaikan masalah e-KTP, dan mapping TPS. Ardiapanto (2019) juga mengatakan DPR RI perlu mempertimbangkan menambahkan aturan khusus mengenai penundaan pencoblosan suara di daerah yang terkena bencana.

Selain ancaman hilangnya hak pilih, persoalan yang sering dikhawatirkan jika terjadi bencana pada saat tahapan pemilu berlangsung adalah rendahnya tingkat partisipasi warga, padahal salah satu indikator keberhasilan pemilu adalah tingkat partisipasinya. Sebagai contoh, di kawasan bencana Gunung Sinabung, KPU Sumut mencatat tingkat partisipasi pemilih pada pemilu 2014 di pengungsian hanya 60 persen dari pengungsi (KPU Sumut, 2014). Di daerah bencana lain seperti Kota Palu, KPU Sulteng untuk melakukan perubahan atau perbaikan DPT setelah masa tanggap darurat terutama pasca meninggalnya 1424 jiwa saat terjadi bencana di Palu (Detik, 2019).

Undang-undang No 7/2017 tentang Pemilihan Umum tidak membahas mengenai kemungkinan adanya penundaan tahapan pemilihan umum akibat bencana alam, kecuali bencana terjadi pada hari pemungutan suara. Ini berarti seluruh tahapan pemilu harus tetap berjalan, sekalipn bencana melanda satu wilayah. Pascatsunami 
Palu, banyak pihak yang mendorong agar tahapan kampanye di wilayah tersebut ditunda, namun KPU menyatakan hal tersebut tidak dapat dilakukan. Dengan begitu, semua tahapan pemilu tetap berlangsung di wilayah itu. Kesepakatan untuk tidak berkampanye di wilayah terpapar bencana justru datang dari peserta pemilu ketika itu, dan KPU mengapresiasi hal tersebut.

Agak berbeda dengan tsunami Palu yang terjadi pada masa kampanye pemilu 2019, erupsi gunung Agung mulai bergeliat pada pertengahan tahun 2017. Sejak Agustus 2017, gempa vulkanik akibat aktivitas Gunung Agung intensitasnya mulai meningkat hingga mencapai 844 kali gempa vulkanik dalam sehari yang dirasakan masyarakat sekitar gunung. Walau sempat menurun aktivitasnya pada Bulan Oktober, namun pada November akhir terjadi beberapa letusan dan semburan abu vulkanik yang berdampak luas. Biro Meteorologi Australia (2017) mencatat kolom letusan mencapai 5,7 km. Letusan pada November 2017 ini menyebabkan 40 ribu orang dievakuasi dari 22 desa di sekitar Gunung Agung.

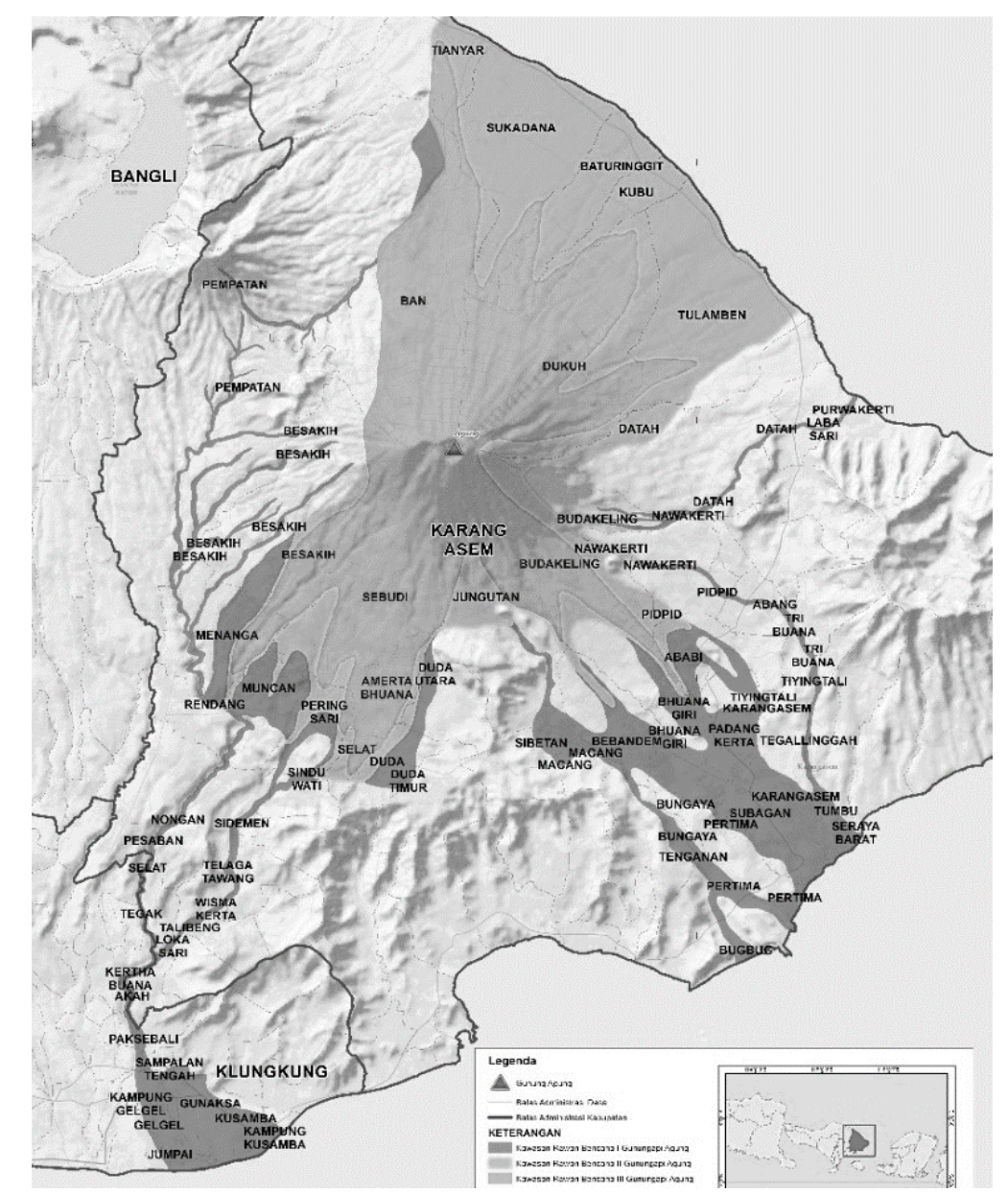

Gambar 1. Peta Rawan Bencana Gunung Agung, Karangasem, Bali. 
Dari catatan KPU Provinsi Bali, jumlah pemilih di Provinsi Bali berdasarkan Daftar Pemilih Tetap (DPT) Tahap 2 Pemilu 2019 per 1 Desember 2019 adalah 3.130.288 orang. Pemilih terbagi di 12.384 TPS di 716 desa/kelurahan pada 57 kecamatan di seluruh Bali. Kabupaten Karangasem sendiri mencapai 380.195 pemilih di 1.706 TPS pada 78 Desa di 8 kecamatan. Menurut Badan Penanggulanagan Bencana Daerah Provinsi Bali, terdapat 28 desa yang berada di kawasan bencana. Desa-desa itu di antaranya Desa Rubaya, Desa Kubu, Desa Dukuh, Desa Batu Ringgit, Desa Sukadana, Desa Ban, Desa Tianyar, Desa Pidpid bagian atas, Desa Nawakerti, Desa Kesimpar, Desa Datah bagian atas, Desa Ababi bagian atas dan barat, Kelurahan Padangkerta, Kelurahan Subagan, Kelurahan Karangasem dekat Tukad Janga, Desa Buana Giri bagian atas, Desa Budakeling, Desa Bebandem bagian atas, dan Desa Jungutan, Desa Duda Utara, Desa Amerta Buana, Desa Sebudi, Desa Peringsari bagian atas, Desa Muncan bagian atas, Desa Besakih, Desa Menanga bagian atas, dan Desa Pembatan bagian atas (IDNTimes, 2019).

Melihat tahapan pemilu 2019, kembali aktifnya Gunung Agung di Karangasem Bali bersinggungan dengan tahapan program dan jadwal penyelenggaraan pemilu tahun 2019. (KPU, 2019) Tahapan pemilu dimulai pada Bulan Agustus 2017, yakni perencanaan program dan anggaran, penyusunan Peraturan KPU, dan sosialisasi. Pada Bulan Agustus hingga Desember 2017, tahapan sedang pada tahap penting yakni pendaftaran dan verifikasi peserta pemilu. KPU Karangasem pada jangka waktu ini tetap menyelenggarakan pendaftaran dan verifikasi peserta pemilu dengan segala hambatan dan tantangannya. Walau memasuki tahun 2018, aktivitas Gunung Agung menurun, namun ancaman akan erupsi Gunung Agung tetap mengintai.

Melihat latar belakang tersebut, maka tulisan ini akan mengangkat dua permasalahan, yakni (1) Bagaimana jalannya tahapan pemilu 2019 di wilayah terdampak erupsi Gunung Agung? dan (2) Apa saja hambatan yang ditemui serta langkah-langkah yang dilakukan penyelenggara pemilu di kabupaten Karangasem dalam menjalankan tahapan pemilu di tengah ancaman erupsi Gunung Agung?

\section{METODE}

Penelitian ini menggunakan metode penelitian kualitatif dengan jenis studi kasus, karena tujuan dari penelitian ini adalah untuk melihat penyelenggaraan Pemilu di daerah yang terancam bencana alam erupsi Gunung Agung, Karangasem, Bali, Indonesia tahun 2019. Dengan demikian, tulisan ini hanya berfokus pada daerah yang terdampak bencana dengan melakukan evaluasi mendalam atas tahapan-tahapan 
pemilu serta mengupas hambatan, tantangan serta langkah-langkah yang diambil untuk mengatasinya.

Pilihan metode kualitatif dengan jenis studi kasus memungkinkan peneliti mengumpulkan informasi mendetail dengan beberapa variasi prosedur pengumpulan data pada periode tertentu (Creswell, 2014: 14). Pengumpulan data primer dilakukan dengan wawancara mendalam dan studi pustaka. Wawancara dilakukan terhadap beberapa narasumber dengan kriteria tertentu. Hal ini dikarenakan narasumber terpilih adalah informan dengan kriteria khusus yang dinilai kompeten dalam menjawab permasalahan (Neuman, 2014:278). Adapun narasumber dalam penelitian ini adalah Ketua KPU Karangasem, I Gede Krina Adi Wedana, Anggota KPU Provinsi Bali, John Darmawan, Ketua Pasebaya Agung Karangasem I Gede Parwana, Anggota KPU Karangasem Ngurah Gede Maharjana dan Kasi Kedaruratan dan Logistik BPBD Karangasem, Ni Wayan Asmi Sukmawati.

\section{PEMBAHASAN}

\section{Hak Warga Negara dan Pemilu}

Setiap warga Negara memiliki hak yang sama dalam pelaksanaan demokrasi, equality before the law. Pasal 27 ayat 1 UUD 1945 menjelaskan "Segala warga negara bersamaan kedudukannya di dalam hukum dan pemerintahan dan wajib menjunjung hukum dan pemerintahan itu dengan tidak ada kecualinya". Prinsip kesetaraan terdapat pada ketentuan konstitusi mengenai HAk Asasi Manusia pasal $28 \mathrm{I}$ ayat 2 tentang adidisktiminasi bagi setiap warga Negara dan pasal 28D. Kesetaraan pun diwujudkan dalam konteks kehidupan berbangsa dan bernegara pasal $28 \mathrm{H}$ ayat 2 yang menjelaskan "Setiap orang berhak mendapat kemudahan dan perlakuan khusus untuk memperoleh kesempatan dan manfaat yang sama guna mencapai persamaan dan keadilan.

Pengungsi akibat bencana alam dapat dikategorikan sebagai kelompok rentan. Muktiono (2009) menjelaskan pengungsi akibat bencana alam atau lingkungan pada saat ini jumlahnya lebih besar daripada pengungsi akibat perang. Oleh karena itu pengungsi akibat bencana alam atau lingkungan termasuk dalam kelompok yang dijamin perlindungan dan pemenuhan aspek Hak Asasi Manusia termasuk menyalurkan hak politiknya.

Pasal 21 Deklarasi Umum Hak Asasi Manusia membahas mengenai hak setiap orang dalam demokrasi, yakni:

(1) Everyone has the right to take part in the government of his country, directly or through freely chosen representatives 
(2) Everyone has the right to equal access to public service in his country

(3) The will of the people shall be the basis of the authority of government Pasal 43 Undang-Undang No 39/1999 tentang Hak Asasi Manusia menyebutkan:

(1) Setiap Warga Negara berhak untuk dipilih dan memilih dalam pemilihan umum berdasarkan persamaan hak melalui pemungutan suara yang langsung, umum, bebas, rahasia, jujur, dan adil sesuai dengan ketentuan peraturan perundangundangan.

(2) Setiap warga Negara berhak turut serta dalam pemerintahan dengan langsung dipilihnya dengan bebas, menurut cara yang ditentukan dalam peraturan perundang-undangan.

Pemilu adalah sebuah mekanisme penting dalam perwujudan prinsip-prinsip demokrasi yang dijamin oleh hukum Hak Asasi Manusia Internasional dan Nasional. Dasar hukum yang telah diratifikasi oleh Indonesia yakni di antaranya Pasal 2 dan Pasal 25 Kovenan International tentang Hak Sipil dan Politik dan Deklarasi Umum Hak Asasi Manusia. Seluruh dasar ini menjamin pelaksanaan pemilu sewajibnya dilaksanakan dengan anti-diskriminasi sebagai bentuk pelaksanaan prinsip keadilan di mana semua warga Negara memperoleh persamaan hak dalam menyalurkan inspirasi politiknya (Muktiono, 2009).

\section{Bencana Erupsi Gunung Agung Jelang Pemilu 2019}

Dalam rentang tahun 2017 hingga 2019, Gunung Agung di Kabupaten Karangasem menunjukkan peningkatan aktivitas hingga level 3 yakni siaga. Berdasarkan data pusdalops BPBD Provinsi Bali, jumlah pengungsi pada November 2017 mencapai 43.358 jiwa yang tersebar di 229 titik pengungsian di seluruh kabupaten di Bali. KPU Karangasem mendata jumlah pengungsi di Kabupaten Buleleng mencapai 5.992 jiwa, Klungkung (7.790 jiwa), Jembrana (312 jiwa), Badung (549 jiwa), Bangli (864 jiwa), Tabanan (657 jiwa), Gianyar (2.968 jiwa), Karangasem (22.738 jiwa), Denpasar (1.448 jiwa). Jumlah Tempat Pemungutan Suara (TPS) yang rawan yakni sebanyak 478 TPS dengan jumlah pemilih mencapai 105.830 jiwa. Hal ini membuat KPU Karangasem mempersiapkan terjadinya perubahan dalam data Daftar Pemilih Tetap (DPT) Pemilu 2019. Pemuktahiran data dilakukan khususnya di 28 desa lingkar Gunung Agung.

"Dampak dari bencana, DPTHP menjadi tidak clear, tidak memenuhi prinsip komprehensif, mutakhir dan akurat" (wawancara I Gede Krisna Adi Widana, Ketua KPU Karangasem) 


\section{Pemutakhiran Data}

Ngurah Gede Maharjana, anggota KPU Karangasem menyatakan pasca terjadi pengungsian pada November 2017, KPU Karangasem melakukan pendataan pemilh berbasis tempat pengungsian. Pada pemutakhiran data KPU Karangasem bekerjasama dengan instansi terkait yakni Dinas Kependudukan dan Pencatatan Sipil, Badan Penanggulangan Bencana Daerah (BPBD) Karangasem dan Pasebaya Agung. Pasebaya Agung adalah lembaga non formal yang menghimpun dan menaungi desadesa yang berada di zona tidak aman bencana Gunung Agung. Anggota himpunan ini adalah seluruh kepala desa atau perbekel desa.

"Kami menghubungi desa-desa adat setempat untuk mengetahui lokasi pengungsian resmi desa terdampak, data dari Pasebaya sangat membantu kami untuk menelusuri pergeseran lokasi pemilih" (Ngurah Gede Maharjana, anggota KPU Karangasem).

"Kami menyusun data kemana masing-masing warga desa terdampak itu mengungsi. Kemudian kami memantau di desa-desa penyangga tersebut, desa penyangga adalah desa di mana pengungsi tinggal" (I Gede Parwana, Ketua Pasebaya Agung).

Selain melakukan pencocokan data dengan lembaga-lembaga terkait KPU Karangasem juga melakukan pendataan ulang terbatas. Pencocokan dilakukan dengan mengerahkan Panitia Pemutakhiran Data Pemilih (PPDP) dengan melakukan coklit terbatas di daerah terancam bencana.

Pemutakhiran data juga dilakukan untuk memeriksa apakah terdapat masyarakat yang kehilangan e-KTP mereka dan merencanakan perpindahan tempat memilih. KPU Karangasem mendata warga terpapar bencana yang tinggal di pengungsian untuk memastikan apakah terdapat pemilih yang berpindah ke dapil lain. Apabila terdapat pemilih yang berpindah ke dapil lain, maka KPU Karangasem melakukan pencoretan data di DPT asal. Setelah memastikan perpindahan pemilih, maka KPU Karangasem melakukan koordinasi untuk perpindahan pemilih dengan KPU Kabupaten lainnya yang dijadikan tempat perpindahan memilih.

"Koordinasi ini penting agar tidak ada pemilih ganda di DPT dari pemilih yang berpindah tempat memilih" (wawancara I Gede Krisna Adi Widana, Ketua KPU Karangasem).

\section{Pemetaan (Mapping) Tempat Pemungutan Suara}

Usai melakukan pemutakhiran data, KPU Bali dan KPU Karangasem kemudian melakukan pemetaan TPS yang akan dijadikan TPS cadangan apabila terjadi bencana erupsi Gunung Agung. KPU memiliki kewajiban untuk memastikan TPS-TPS di 28 desa terancam bencana masih dalam keadaan layak dan aman untuk menyelenggarakan pemungutan suara. Mapping dilakukan tidak hanya dengan 
observasi langsung namun juga dengan melihat kajian demografinya. Hal ini dilakukan dengan bantuan dari Badan Penanggulangan Bencana Daerah (BPBD) Karangasem.

"Kami dari BPBD membantu memetakan daerah-daerah mana yang masuk ke $\mathrm{KRB}$, apakah masuk ke 4 kilo meter atau enam kilo meter darah rawan bencana" (wawancara Ni Nyoman Asmi Sukmawati, Kasi Kedaruratan dan Logistik BPBD Karangasem).

Setelah melakukan observasi dan kajian demografi, KPU Karangasem menentukan apakah daerah tersebut masih layak didirikan TPS atau tidak. Hal ini untuk menentukan aksesibilitas pemilih menuju ke tempat pemungutan suara. KPU Karangasem pun memastikan persyaratan sebagai TPS terpenuhi sesuai aturan yang berlaku.

"Selain aksesibilitas, KPU juga harus memperhatikan jumlah pemilih di satu TPS yang layak tadi. Berdasarkan aturan jumlah pemilih dalam satu TPS maksimal 300 pemilih. Kita harus menghitung karena apabila pemilihnya terlalu sedikit maka pemilih akan digeser/diarahkan untuk memilih di lokasi TPS lainnya" (wawancara I Gede Krisna Adi Widana, Ketua KPU Karangasem).

Berdasarkan data KPU Karangasem, terdapat 478 TPS yang harus dikelola dan dipindahkan apabila terjadi erupsi Gunung Agung menjelang pemilu atau saat pemungutan suara. TPS cadangan berada di kantung-kantung pengungsi yang telah didata bersama oleh BPBD, Pasebaya Agung dan KPU Karangasem. Rencana mitigasi TPS jelang pemilu disusun bersama hingga tingkat PPS dengan diketahui oleh perbekel atau kepala desa terkait.

Contohnya 24 TPS yang berada di Kawasan bencana di Desa Bungaya Kangin, Bebandem, Karangasem. Ke-24 TPS ini kemudian telah disiapkan tempat TPS yang aman dari bencana apabila terjadi erupsi Gunung Agung. Salah satunya TPS 4 di dusun Kecicang Bali akan pindah ke dusun Bebandem Desa Bungaya Dusun Br. Tengah. Hal ini dikarenakan saat pengungsian di akhir November, warga Dusun Kecicang mengungsi ke Dusun Bungaya.

\section{Pendataan Ulang Anggota PPK, PPS, dan Logistik Pemilu}

Setelah melakukan pendataan pemilih, dan rancangan TPS cadangan bila TPS sebelumnya masuk dan terdampak bencana, hal yang harus dipastikan siap berikutnya adalah pendataan ulang penyelenggara pemilu, yakni anggota PPK dan PPS. Untuk itu KPU Karangasem pasca naiknya level Gunung Agung menjadi awas, melakukan pendataan ulang jumlah anggota PPK dan PPS. KPU Karangasem melakukan pendataan apakah ada anggota penyelenggara pemilu yang meninggal, hilang, lukaluka, dan mengungsi. 
"Kami di KPU Karangasem berencana mengangkat anggota PPK atau PPS baru dari mereka di pengungsian, agar pelaksanaannya dapat lebih fokus dan efektif" (wawancara I Gede Krisna Adi Widana, Ketua KPU Karangasem).

Setelah melakukan pendataan, KPU Karangasem memastikan kesediaannya kembali untuk bertugas dalam pemilu 2019. Namun KPU Karangasem juga merancang rencana cadangan apabila ada perubahan atau pergeseran tempat pemungutan suara terutama pada pendistribusian logistik. Hal ini terkait dengan sistem distribusi dan keamanan logistik.

"Setelah menentukan titik-titik untuk TPS pindahan bila terjadi bencana erupsi Gunung Agung, maka yang harus dipikirkan adalah peralatan penunjang pemilu seperti bilik suara, kotak suara dan surat suara" (wawancara I Gede John Darmawan, Anggota KPU Provinsi Bali).

KPU Bali dan KPU Karangasem menyusun skenario bagaimana pendistribusian logistik pemilu bila terjadi bencana tiba-tiba saat tahapan pemilu 2019. Ironisnya KPU Bali mengaku tidak memiliki dana untuk pemindahan logistik pemilu yang telah terdistribusi ke TPS-TPS yang berada di Kawasan rawan bencana.

"Skenario sudah ada, kemana harus berpindah bila tiba-tiba Agung Meletus sudah ada, masyarakat pun sudah paham, tapi dari mana ongkos untuk memindahkan kotak suara, bilik suara itu yang kami tidak punya" (wawancara I Gede John Darmawan, Anggota KPU Provinsi Bali).

Pemindahan logistik pemilu dapat dilakukan secara mendadak bila terjadi bencana. KPU Bali dan KPU Karangasem telah memiliki 3 rencana mitigasi bencana. Hal ini merupakan hasil kolaborasi Bersama antara KPU Bali, KPU Karangasem, BPBD, Pasebaya Agung dan instansi terkait lainnya.

\section{Rencana Mitigasi Bencana}

Setelah menyusun rancangan di TPS desa-desa penyangga, maka KPU membuat skenario apabila terjadi bencana sebelum, saat dan setelah pemungutan suara. Apabila bencana terjadi sebelum tanggal 17 April 2019, maka (1) TPS akan didirikan sesuai dengan lokasi tempat pengungsian sesuai dengan arahan perbekel atau kepala desa yang telah disusun pada pemutakhiran data di atas, (2) semua personil penyelenggara baik KPPS, PPS dan PPK se-kecamatan yang kena kawasan bencana melaksanakan pemilihan di lokasi pengungsian.

“Jadi apabila terjadi bencana sebelum tanggal 17 April, TPS akan segera kami pindahkan dan kami dirikan sesuai dengan mapping TPS mitigasi bencana, di 478 lokasi TPS baru" (wawancara I Gede John Darmawan, Anggota KPU Provinsi Bali). 
Apabila terjadi bencana pada tanggal 17 april 2019 sebelum pukul 07.00 maka pelaksanaan pemilihan akan dihentikan oleh KPPS atas persetujuan pengawas TPS dan saksi serta logistik akan dibawa ke pengungsian.

"Bila terjadi pada tanggal 17 namun sebelum pukul 07.00 maka proses pemungutan suara akan dihentikan dengan kesepakatan pihak-pihak terkait, lalu logistik dan TPS kita pindahkan ke TPS Mitigasi bencana tempat pengungsian" (wawancara I Gede John Darmawan, Anggota KPU Provinsi Bali).

Apabila terjadi bencana pada tanggal 17 April 2019 setelah jam 07.00 maka pelaksanaan pemilihan akan dihentikan oleh KPPS atas persetujuan pengawas TPS dan saksi serta logistik akan dibawa ke pengungsian dengan ketentuan semua logistik dimasukkan ke kantong plastik pembungkus kotak.

Indonesia merupakan negara yang sangat rawan bencana. Menjelang pemilu 2019 lalu terjadi beberapa bencana yang sempat dikhawatirkan mengganggu kelancaran pemilu 2019. Bencana seperti gempa Lombok, tsunami Palu, erupsi gunung Anak Krakatau, dan erupsi Gunung Agung adalah sedikit dari rentetan bencana yang terjadi ketika tahapan pemilu serentak 2019 tengah dilaksanakan. Ada beberapa hal dalam proses pemilu serentak yang potensial terkena ekses serius akibat bencana alam, seperti DPT, Kampanye, pemungutan suara, dan partisipasi pemilih. Seluruhnya berkaitan dengan kualitas dari pemilu itu sendiri.

Bencana sering kali membawa dampak pada adanya sejumlah penduduk yang meninggal atau mengungsi. Kondisi ini salah satunya berdampak pada Daftar Pemilih Tetap Hasil Perbaikan (DPTHP) yang tidak memenuhi prinsip komprehensif, mutakhir, dan akurat. Dalam kondisi demikian, KPU setempat diwajibakan melakukan Coklit terbatas dan berkoordinasi dengan beberapa pihak seperti BPBD dan Disdukcapil untuk menghasilkan DPT yang clear.

Hal berikutnya yang sering menjadi sorotan dalam topik pembahasan tentang pemilu dan bencana alam adalah proses kampanye. Aktivitas kampanye di lahan eks korban bencana maupun di pengungsian sangat rawan dengan konflik dan pergesekan. Selain itu, kampanye di eks korban bencana disinyalir rawan politik uang. Hal ini mudah dipahami karena di kawasan ini pada umumnya masyarakat tengah menderita dan mengalami kesulitan ekonomi.

Menjelang pemilu 2019, KPU tidak dapat menghentikan sementara tahapan kampanye di wilayah terdampak bencana. Namun demikian, KPU RI mengeluarkan himbauan agar tidak berkampanye di daerah terdampak bencana, karena akan 
menciderai rasa kemanusiaan. Beberapa kontestan pemilu ketika itu juga menayatan tidak akan berkampanye di wilayah terdampak bencana dan di pengungsian.

Selain hal-hal di atas, penyelenggara Pemilu arus mengantisipasi kemungkinan terjadinya bencana baik sebelum maupun saat pemungutan suara. Jika mengacu kepada UU No. 7 tahun 2017 tentang Pemilu terdapat sejumlah pasal dan ayat mengatur inwal kegiatan pemungutan suara ulang, penghitungan suara dan rekapitulasi suara ulang. Pada Pasal 372 misalnya ayat (1), pemungutan suara di TPS dapat diulang apabila terjadi bencana alam dan/atau kerusuhan yang mengakibatkan hasil pemungutan suara tidak dapat digunakan atau penghitungan suara tidak dapat dilakukan (akurat.co, 2018)

Ekses berikutnya dari pemilu di wilayah terdampak bencana adalah kemungkinan rendahnya tingkat partisipasi warga di daerah terdampak. Hal ini mengingat beban yang tengah dihadapi pemilih terpapar dan tertama terdampak sangat besar. Jangankan untuk memikirkan Pemilu, memikirkan masa depannyapun sulit, apalagi bagi pemilih yang semua harta bendanya luluh lantak di terjang bencana. Banyak pihak yang menyebutkan agak sulit untuk daerah terdampak bencana mencapai angka partisipasi yang tinggi karena kondisi psikologis masyarakatnya yang demikian.

Untuk kasus wilayah terdampak bencana erupsi gunung Agung di kabupaten Karangasem Bali, diketahui bahwa tingkat partisipasi warganya cukup tinggi, bahkan melampaui target partisipasi nasional yang dipatok pada angka $77,5 \%$. Tingkat partisipasi pemilih Karangasem dalam pemilu 2019 mencapai angka 78,5\%, sedikit lebih tinggi dibanding tingkat partisipasi warga dalam Pilkada Bali di wilayah tersebut pada tahun 2018. (gatra.com, 2019) Hal ini terjadi karena adanya beberapa alasan, salah satunya adalah komunikasi dan koordinasi berbagai stakeholder di Karangasem. Koordinasi dan komunikasi KPU Karangasem dengan BPBD, Dinas Kependudukan dan Catatan Sipil, KPU Bali, dan Pasemetonan/Persaudaraan Jagabaya Gunung Agung (Pasebaya Agung) nampak membawa pengaruh pada tingkat partisipasi pemilih.

Aktor yang disebut terakhir merupakan stakeholder yang membedakan wilayah terdampak bencana gunung Agung dengan wilayah terdampak bencana lainnya di Indonesia. Pasebaya Agung ini adalah organisasi berbasis kearifan lokal dalam kegiatan edukasi, mitigasi, serta informasi pengurangan risiko bencana sejak terjadinya peningkatan aktivitas Gunung Agung. Pasebaya ini beranggotakan 28 kepala desa yang berada di lingkar Gunung Agung dengan radius $12 \mathrm{~km}$ sesuai dengan rekomendasi Pusat Vulkanologi dan Mitigasi Bencana Geologi. 
(mediaindonesia.com, 2019) Pasebaya Agung melakukan koordinasi dengan Badan Penanggulangan Bencana Daerah (BPBD) dan Komisi Pemilihan Umum (KPU) Karangasem merencanakan kedua skenario yang terkait dengan lokasi tempat pemungutan suara (TPS). Pertama, skenario 6 kilometer, dan kedua, skenario $12 \mathrm{~km}$. (rri.co.id, 2019) Koordinasi tersebut menghasilkan kesepakatan (MoU) dengan desa terdampak dan desa penyangga. Dengan demikian memudahkan dalam penempatan TPS bila terjadi dalam keadaan darurat.

Dari pengalaman penyelenggaraan Pemilu di kabupaten Karangasem yang mewilayahi Gunung Agung, terdapat satu hal penting yang perlu digarisbawahi. KPU Karangasem sebagai penyelenggara pemilu di daerah tersebut tidak saja berkoordinasi dengan BPBD dan Disdukcapil Karangasem, namun juga berkoordinasi intens dengan Pasebaya Agung. Hal ini memungkinkan KPU Karangasem dapat dengan cepat mengetahui lokasi-lokasi pengungsian warga desa adat terdampak. Pendataan (mapping) dan berbagai proses lainnya dapat dilakukan dengan lebih cepat dan tepat.

Catatan penting yang juga dapat dipelajari dari penyelenggaraan pemilu di wilayah terdampak erupsi gunung Angung di Karangasem Bali adalah koordinasi antara KPU Karangasem dengan aktor non formal seperti Pasebaya Agung yang sangat penting karena konteks dan kultur lokal masyarakat di daerah tersebut yang sangat menaati perangkat desa adat. Selain itu, koordinasi dengan Disdukcapil dan BPBD setempat juga tetap dilakukan. Ini membawa pesan bahwa penyelenggara pemilu di level daerah sangat penting melakukan koordinasi dengan berbagai stakeholder yang berkaitan dengan kebencanaan, baik aktor-aktor formal maupun non formal.

Koordinasi tersebut dapat memberi solusi pada penyelenggaraan pemilu di wilayah terdampak bencana, meski memang pihak KPU Bali maupun Karangasem mengakui, tidak ada anggaran khusus untuk mitigasi bencana. Operasional Pasebaya Agung dibantu oleh BPBD dan Dinas Kominfo. Untuk ke depannya, sangat penting untuk membuat aturan pada level PKPU guna mengatur pemilu di wilayah terdampak bencana, bukan saja himbauan seperti yang dilakukan hingga pemilu 2019.

\section{PENUTUP}

Ancaman bencana erupsi Gunung Agung menyebabkan permasalahan di berbagai tahapan pemilu 2019. Aspek-aspek yang harus diperhatikan adalah daftar pemilih, logistik pemilu, verifikasi peserta pemilu, anggaran, sosialisasi, kampanye, 
pemungutan suara, dan tingkat partisipasi pemilih dalam pemilu. Hampir semua permasalahan tersebut dapat ditangani dengan baik dalam pemilu serentak tahun 2019 di kabupaten Karangasem. Tingkat partisipasi pemilih menjadi salah satu tolok ukurnya. Angka partisipasi pemilih di Karangasem pada tahun 2019 lebih tinggi dibanding target angka partisipasi nasional.

Tahapan pemilu di Karangasem dapat berjalan baik meski berada di tengah ancaman bencana erupsi gunung Agung disebabakan oleh berbagai faktor. Salah satu faktor penting yang menjadi catatan penting dari pemilu di wilayah terdampak erupsi gunung Agung yang dapat dicontoh oleh wilayah lain yang mungkin terdampak bencana dan sedang melaksanakan momentum elektoral adalah adanya komunikasi dan koordinasi yang sangat baik antara penyelenggara pemilu dengan stakeholder formal dan informal. Stakeholder formal dalam hal ini adalah lembaga pemerintah seperti BPBD dan Disdukcapil setempat. Sedangkan stakeholder informal yang dimaksud dalam hal ini adalah organisasi berbasis kearifan lokal seperti Pasebaya Agung yang memiliki peran sangat besar dalam edukasi, mitigasi, serta informasi pengurangan risiko bencana. Komunikasi dan koordinasi yang baik itu akhirnya melahirkan beberapa skenario yang disiapkan bila Gunung Agung mengalami erupsi pada saat hari $\mathrm{H}$ pemungutan suara. Semua stakeholder benar-benar memahami apa yang menjadi perannya jika bencana datang di hari pencoblosan.

\section{REFERENSI}

Ardipandanto, Aryojati. 2019. Pemutakhiran Data Pemilih Tetap Pemilu 2019 di Daerah Bencana Alam. INFO Singkat Kajian Singkat terhadap Isu Aktual dan Strategis. Vol XI No.1/Puslit/Januari/2019. 25-30Beetham, David. 1994. Defining and Measuring Democracy. London: Sage Pub.

Creswell, John. W. 2014. Research Design: Qualitative, Quantitative and Mixed Methods Approches. USA : Sage Publications

Muktiono. 2009. Penegakan Hak atas Demokrasi Kelompok Rentan dalam Pelaksanaan Pemilihan Umum di Indonesia dalam Sudut Pandang Hak Asasi Manusia. Jurnal Konstitusi Vol II No 1, Juni 2009, 7-31

Neuman, Lawrence. 2014. Social research Method: Qualitative and Quantitative Approaches $7^{\text {th }}$ ed. UK: Pearson.

\section{Sumber Online}

Akurat.co. 2019."Kerawanan Pemilu di Daerah Bencana” https://akurat.co/news/id456845-read-kerawanan-pemilu-di-daerah-bencana diakses tanggal 13 Oktober 2019, Pukul 14.20 WITA.

Australian Government Bureau of Meteorology. 2017. "Volcanic Ash Update for Mount Agung" sumber: http://media.bom.gov.au/releases/398/volcanic-ash-update-formount-agung/ diakses 12 Oktober 2019. 
Detik. 2019. "Bencana dan Tahapan Pemilu" sumber: https://news.detik.com/kolom/d4269053/bencana-dan-tahapan-pemilu diakses 11 Oktober 2019.

IDNTimes. 2019. "KPU Bali Petakan TPS Rawan di Gunung Agung” sumber : https://bali.idntimes.com/news/bali/imamrosidin/kpu-bali-petakan-tps-rawan-digunung-agung/full diakses 12 Oktober 2019.

Gatra. 2019. "Ini Hasil Rekapitulasi Partisipasi Pemilih pada Pemilu 2019 di Bali” sumber : https://www.gatra.com/detail/news/416908/politic/ini-hasil-rekapitulasipartisipasi-pemilih-pada-pemilu-2019-di-provinsi-bali diakses tanggal 10 Oktober 2019, Pukul 21.35 WITA.

KPU.go.id, “Tahapan pada Pileg 2019”, Sumber: https://infopemilu.kpu.go.id/pileg2019 diakses tanggal 13 Oktober 2019.

KPU Sumut. 2019. "Tingkat Partisipasi Pemilih di Pengungsian Capai 60 Persen", sumber: https://kpud-sumutprov.go.id/?p=1208 diakses tanggal 11 Oktober 2019.

Media Indonesia. 2019. "Ini Sebabnya Pemilu di Karangasem Dibuat Dua Skenario" https://mediaindonesia.com/read/detail/216458-ini-sebabnya-pemilu-dikarangasem-dibuat-dua-skenario diakses 15 Oktober 2019, Diakses 15 Oktober 2019, Pukul 16.41 WITA.

RRI.co. 2019.“Ini Strategi KPU Hadapi Gunung Agung” sumber:

http://rri.co.id/post/berita/662110/pemilu 2019/ini strategi kpu hadapi gunung agung.html Diakses 15 Oktober 2019, Pukul 16.45 WITA. 